\title{
Pengaruh Media Pengasapan terhadap Kualitas Eksterior dan Organoleptik Telur Asin Asap
}

\section{(The Effect of Smoked Media on the Exterior Quality and Organoleptic of Salted Smoked Eggs)}

\author{
Eva Fajriana, Achmad Jaelani, \& Aam Gunawan \\ Program Studi Peternakan Fakultas Pertanian Universitas Islam Kalimantan Muhammad Arsyad Al \\ Banjari, Banjarmasin, Kalimantan Selatan \\ Penulis korespondensi : ach_jaelaniborneo@yahoo.com
}

\begin{abstract}
ABSTRAK
Telur itik merupakan telur yang sering diolah menjadi telur asin. Namun sekarang perlu dicarikan alternatif lain dari pengolahan telur itik ini dengan rasa yang berbeda, selain berasa asin juga terdapat rasa asap. Penelitian ini bertujuan untuk menganalisis pengaruh media fumigasi terhadap kualitas eksterior dan organoleptik telur asin asin. Metode yang digunakan adalah metode eksperimen. Fumigasi dilakukan 48 jam untuk setiap media fumigasi. Metode penelitian menggunakan Rancangan Acak Lengkap (RAL) dengan lima perlakuan dan empat ulangan (5x4) dalam total 20 unit penelitian yang terdiri dari $m_{0}=$ tanpa pengasapan (kontrol), $m_{1}=$ media pengasapan menggunakan serat kelapa, $m_{2}=$ media pengasapan menggunakan serbuk gergaji, $m_{3}=$ media pengasapan menggunakan sekam padi, dan $m_{4}=$ media pengasapan menggunakan kulit galam. Data kualitas eksterior yang diperoleh dilakukan dengan data uji homogenitas dan ANOVA. Jika analisis varians secara signifikan berbeda atau sangat nyata dilakukan dengan menggunakan uji nilai tengah menggunakan Uji Jarak Berganda Duncan (DMRT). Sedangkan analisis hasil uji organoleptik yang diperoleh dilakukan dengan menggunakan uji Kruskal Wallis kemudian Duncan Multiple Range Test (DMRT). Hasil penelitian menunjukkan bahwa media pengasapan berpengaruh terhadap pasir dan aroma khas telur asin asin. Media pengasapan bertindak pada pengurangan berat telur asin yang diasinkan. Media pengasapan kulit kayu galam dan serat kelapa memiliki pasir paling tinggi di antara media lainnya. Namun, media berasap dari kulit kayu galam memiliki penyusutan berat telur terbesar.
\end{abstract}

Kata kunci: Media pengasapan, serat kelapa, serbuk gergaji, sekam padi, kulit kayu galam.

\section{ABSTRACT}

Duck eggs that are often processed into salted eggs. But now it is necessary to look for other alternatives from processing these duck eggs with different tastes, besides taste salty there is also a sense of smoked.This study aims to analyze the effect of fumigation media on the exterior quality and organoleptic of salted smoked eggs. The method was used an experimental method. Fumigation was carried out 48 hours for each fumigation media. The research method used a Completely Randomized Design (CRD) with five treatments and four replications (5x4) in a total of 20 research units consist of $m_{0}=$ no fumigation (control), $m_{1}=$ fumigation media using coconut fiber, $m_{2}=$ fumigation media using sawdust, $m_{3}=$ fumigation media using rice husk, and $m_{4}=$ fumigation media using galam bark. Exterior quality data obtained were carried out by homogeneity test data and ANOVA. If the analysis of variance is significantly different or very real it's done by means of the middle value test using the Duncan Multiple Range Test (DMRT). While the analysis of the organoleptic test results obtained was performed using the Kruskal Wallis test then Duncan Multiple Range Test (DMRT). The results showed that the fumigation media effected to the sand and the typical aroma of salted smoked eggs. The fuming media acts on the weight reduction of salted smoked eggs. Galam bark fuming media and coconut fiber has the highest sandiness among other media. However, the smoked media from galam bark had the biggest egg weight shrinkage.

Keywords: Smoked media, coconut fiber, sawdust, rice husk, galam bark.

Article History Submitted: April 10, 2020

Approved with minor revision: May 8, 2020

Accepted: May 21, 2020

Published: May 30, 2020 


\section{PENDAHULUAN}

Telur itik cukup populer dan tersedia dalam jumlah banyak di Kalimantan Selatan. Telur itik merupakan salah satu sumber protein hewani yang memiliki rasa yang lezat, mudah dicerna, dan bergizi tinggi. Telur itik memiliki kandungan protein $13,1 \%$, lemak $14,3 \%-17 \%$, vitamin, dan mineral. Akan tetapi, tingginya kadar protein telur itik menyebabkan daya simpan telur menjadi rendah. Ditambah jumlah telur yang banyak tanpa adanya perlakuan pasca panen menyebabkan telur mudah rusak.

Pengasinan telur merupakan teknologi pengolahan hasil ternak yang peminatnya cukup banyak. Sebagian besar telur asin dibuat dari telur itik. Hal ini disebabkan telur itik mempunyai pori-pori yang besar sehingga baik untuk telur asin. Semakin lama waktu pengasinan akan semakin tahan lama masa simpan telur (awet). Pengawetan telur asin dapat dilakukan dengan cara perendaman dalam larutan garam atau menggunakan tambahan campuran bahan lain seperti abu gosok dan batu-bata. Akan tetapi, perendaman telur dalam larutan garam hanya dapat mempertahankan umur telur asin selama 3 hari saja (Novia et. al., 2012). Prinsip dari pengawetan khususnya telur konsumsi adalah mencegah masuknya mikrobia ke dalam telur, dan mencegah penguapan air dan gas-gas dari dalam telur yang melewati pori-pori kerabang telur yang berjumlah 7.000 sampai 17.000 (Marsudin, 2009). Pengawetan telur yang banyak dan sampai sekarang paling dikenal serta paling digemari oleh masyarakat adalah telur asin. Tujuan utama dari proses pengasinan telur ini selain membuang rasa amis dan menciptakan rasa yang khas adalah untuk memperpanjang masa simpan telur (Amir et. al., 2014).

Menurut Munir dan Wati (2014), pengasinan tidak hanya mempengaruhi daya simpan, karakteristik fisik, kimia maupun organoleptik dari telur asin saja, namun juga mempengaruhi nilai gizinya. Telur asin adalah telur yang diolah dalam keadaan utuh, dimana kandungan garam dapat menghambat perkembangan mikroorganisme dan sekaligus memberikan aroma khas, sehingga telur dapat disimpan dalam waktu yang relatif lama (Wasito dan Rohaeni 1994). Menurut Widjaja (2003) bahwa telur asin merupakan telur segar yang diawetkan dengan menggunakan garam. Salah satu cara yang dilakukan untuk memperpanjang umur simpan telur asin adalah dengan pengasapan.

Metode pengasapan telur dapat dijadikan salah satu metode pengawetan lanjutan dari metode pengasinan telur. Pengasapan telur selama 12 jam yang dilakukannya juga menuntut sumber asap yang khas. Media yang cocok untuk pengasapan telur adalah batok kelapa dan sekam. Proses pengasapan menggunakan media tersebut memiliki beberapa kelebihan dibandingkan dengan telur asin rebus yaitu, warna lebih menarik coklat kehitaman, bau amis pada telur asin hilang, berbau khas asap apalagi bila menggunakan arang batok kelapa baunya harum manis, tahan lebih lama sekitar 1 bulan dibandingkan dengan telur asin rebus yang hanya tahan 1 minggu (Novia et. al., 2012).

Pengasapan dapat dilakukan dengan metode dingin atau dengan metode panas (Ahmad, et. al., 2016). Cara pengolahan telur dengan metode pengasapan dinilai dapat memberikan rasa yang unik dan spesifik (Widyastuti, et. al., 2012), sehingga bisa menambah nilai jual telur asin. Jika saat ini telur asin bisa dihargai $\mathrm{Rp}$ 2500-3000, maka telur asin asap dihargai Rp 5000 bahkan lebih. Pengasapan juga dapat memperpanjang masa simpan (Simanjuntak, et. al., 2013), sehingga dapat digunakan untuk kepentingan distribusi sampai ke pelosok daerah. Hingga saat ini produk telur itik asap masih belum lazim dijumpai dan belum banyak penelitian mengenai produk ini.

Pengasapan merupakan salah satu cara pengawetan yang paling tua, namun pada perkembanganya pengasapan lebih ditekankan pada kualitas sensori atau organoleptik dari pada efek pengawetanya (Djaafar, 2007). Menurut penelitian Novia et. al., (2012) lama pengasapan selama 8 jam dapat menghasilkan kadar protein 
48,99\%, kadar lemak 45,82\%, warna 3,35 (biasa), rasa 3,49 (suka), aroma 2,73 (biasa) dan tekstur 3,16 (biasa). Proses pengasapan pada telur merupakan salah satu cara untuk mengawetkan telur dalam jangka waktu yang lama, hal ini dikarenakan oleh asap menutup pori-pori yang terdapat pada telur (Jaelani dan Zakir, 2018). Akibat pengasapan selain berpengaruh terhadap karakteristik kimia (air, protein, lemak, abu dan $\mathrm{NaCl}$ ). Pengasapan, selain berfungsi sebagai pengawetan, juga menciptakan warna, cita rasa yang spesifik dan menghambat mikroba (Novia et. al., 2012).

Penentuan dan pengukuran kualitas telur mencakup dua hal yakni kualitas eksterior dan interior. Kualitas eksterior ditentukan oleh warna, bentuk, tekstur, keutuhan, dan kebersihan kerabang telur (Rifaid, 2018). Kualitas interior telur dapat dilihat dengan candling/peneropongan dan susut bobot telur. Adanya peneropongan pada telur akan membantu kita untuk mengetahui kondisi kulit telur, ukuran rongga udara dan pergeseran kuning telur (Chandra, 2014).

Susut bobot telur adalah suatu cara penghitungan penyusutan telur dari sebelum diberikan perlakuan sampai setelah diberikan perlakuan. Susut bobot telur perlu diamati untuk mengetahui seberapa besar terjadinya penguapan air dan hilangnya karbondioksida dari putih telur melalui kulit telur (Sutiasih et. al., 2017). Susut bobot telur sangat dipengaruhi keadaan awal dari telur. Penyusutan bobot telur akan bertambah besar dengan bertambahnya umur simpan sampai batas tertentu dan selanjutnya bobot telur akan relatif konstan.

Pengujian organoleptik adalah ilmu pengetahuan yang menggunakan indera manusia untuk mengukur tekstur, warna, bentuk, aroma dan flavor suatu produk pangan. Uji organolepik dapat dinilai dari lima tahapan yaitu menerima produk, mengenali produk, mengadakan klasifikasi sifat-sifat produk, mengingat kembali produk yang telah diamati, dan menguraikan kembali sifat indrawani produk. Uji organoleptik memiliki relevansi yang tinggi dengan mutu produk karena berhubungan langsung dengan selera konsumen (Ayustaningwarno, 2014). Adapun faktor-faktor yang menentukan uji organoleptik antara lain Warna, Rasa, Tekstur, dan Aroma. Warna merupakan daya tarik dari suatu makanan. Setidaknya dalam suatu hidangan makanan harus terdiri dari dua atau tiga warna makanan yang berbeda (Hasrah, 2017). Dalam pengujian warna pada telur asin terdiri warna kerabang, warna kuning telur, dan warna putih telur. Menurut hasil penelitian Oktaviani et. al., (2012), bahwa warna kuning telur sebelum mengalami proses pengasinan adalah kuning, warna akan berubah menjadi kuning kecoklatan, cokelat tua, orange atau kuning cerah setelah melalui proses pengasinan.

Adapun hipotesis yang akan diuji apakah media pengasapan akan berpengaruh terhadap kualitas eksterior dan organoleptik pada telur asin asap. Media yang biasa digunakan agar dapat menghasilkan asap yang awet yaitu serbuk gergaji kayu, sabut kelapa, kulit kayu, dan sekam padi. Serbuk gergaji kayu merupakan limbah yang masih jarang dimanfaatkan. Menurut penelitian Baharudin (2005) kandungan kimia serbuk gergaji kayu adalah selulosa $60 \%$, lignin 28 $\%$ dan zat lain (termasuk zat gula) $12 \%$. Abu sabut kelapa mengandung unsur Magnesium ( $\mathrm{Mg}$ ) dan Kalium (K) yang akan membentuk garam $\mathrm{MgCl} 2$ dan $\mathrm{KCl}$, sehingga makanan bisa menjadi asin oleh unsur $\mathrm{Cl}$ tersebut. Komponen kimia yang terdapat dalam kulit kayu. Sekam padi memiliki kandungan kimia yang terdiri atas $50 \%$ selulosa, $25-30 \%$ lignin dan $15-20 \%$ silika (Haryadi, 2006).

\section{METODE PENELITIAN}

\section{Waktu dan Tempat}

Penelitian dilakukan pada Bulan Februari-Maret 2020 di Jl. Pondok Kelapa No. 16 Komplek Balitra Jaya Permai RT. 01 RW. VIII Loktabat Utara Banjarbaru Utara serta Laboratorium Terapan Fakultas Pertanian Universitas Islam Kalimantan Muhammad Arsyad Al Banjari di Banjarmasin. 


\section{Bahan dan Alat}

Bahan utama yang digunakan adalah telur itik 200 butir, garam $2 \mathrm{~kg}$, tanah liat 3 $\mathrm{kg}$, air secukupnya, abu gosok secukupnya, kulit kelapa $40 \mathrm{~kg}$, serbuk gergaji $40 \mathrm{~kg}$, sekam $20 \mathrm{~kg}$, kulit kayu galam 50kg.

Adapun beberapa alat yang digunakan adalah ember digunakan untuk menyimpan telur selama pemeraman telur asin, baskom digunakan untuk menyimpan telur pada proses pengasinan telur, serbet kain digunakan pada waktu proses pembalikan telur asin asap selama proses pengasapan, timbangan digital digunakan untuk menimbang telur sebelum dan sesudah pengasapan, tungku pengasap digunakan pada saat proses pengasapan telur asin asap dengan media yang berbeda.

\section{Metode Penelitian}

Penelitian ini dilakukan berdasarkan metoda eksperimen, dengan menggunakan media pengasapan yang berbeda. Pengasapan dilakukan selama 48 jam. Pada penelitian ini menggunakan Rancangan Acak Lengkap (RAL) dengan lima perlakuan dan empat ulangan $(5 \times 4)$ total 20 unit.

Perlakuan pada penelitian ini adalah sebagai berikut :

$$
\begin{aligned}
\mathrm{m}_{0}= & \text { Tanpa media pengasapan } \\
\mathrm{m}_{1}= & \text { Media pengasapan menggunakan } \\
& \text { sabut kelapa } \\
\mathrm{m}_{2}= & \text { Media pengasapan menggunakan } \\
& \text { serbuk gergaji } \\
\mathrm{m}_{3}= & \begin{array}{l}
\text { Media pengasapan menggunakan } \\
\text { sekam }
\end{array} \\
\mathrm{m}_{4}= & \begin{array}{l}
\text { Media pengasapan menggunakan } \\
\text { kulit kayu galam }
\end{array}
\end{aligned}
$$

Model umum rancangan yang digunakan adalah sebagai berikut :

dimana :

$$
Y i j=\mu+\alpha i+\varepsilon i j
$$

Y ij : Nilai hasil pengamatan pada perlakuan media pengasapan yang berbeda terhadap telur asin asap.

$\mu$ : Nilai rata-rata umum pengamatan

$\alpha \mathrm{i}$ : Pengaruh konsentrasi media pengasapan terhadap susut bobot telur asin asap.

Eij : Galat percobaan akibat perlakuan ke- i dan ulangan ke-j.

\section{Variabel Yang Diamati}

Adapun variabel yang diamati pada penelitian ini adalah sebagai berikut :

1) Kualitas eksterior terdiri atas susut bobot telur (\%).

2) Organoleptik terdiri atas kemasiran, tekstur, aroma khas asap, dan tingkat kesukaan.

\section{Persiapan Pembuatan Telur Asin}

Telur asin dibuat berdasarkan hasil modifikasi dari metode yang digunakan oleh Jaelani dan Zakir (2018). Pembuatan telur asin meliputi tahapan :

1) Telur itik diseleksi dengan kriteria tidak retak dan bagus (telur itik berumur $\leq 1$ minggu dikumpulkan).

2) Telur yang terseleksi dipisahkan antara telur itik yang retak dan tidak retak dengan mencelupkan telur kedalam gelas berisi air (telur retak/rusak akan mengambang).

3) Telur itik dibersihkan dari kotoran dengan air bersih.

4) Adonan dibuat dari tanah liat dan garam dengan komposisi 3:1, kemudian tambahkan air secukupnya hingga terbentuk pasta. Telur dibungkus dengan adonan tersebut satu-persatu hingga menutupi seluruh permukaan telur (ketebalan $\pm 1 / 5 \mathrm{~cm}$ ).

5) Telur itik dibungkus/dibaluri lagi dengan abu gosok secara berlapis-lapis.

6) Telur diperam selama 12 hari di tempat teduh dan terbuka.

\section{Pembuatan Telur Asin Asap}

Sebanyak 200 butir telur asin yang telah diperam selama 12 hari dibagi dalam 5 kelompok perlakuan, yaitu $\mathrm{m}_{0}$ (tanpa pengasapan), $\mathrm{m}_{1}$ (lama pengasapan $48 \mathrm{jam}$ ), $\mathrm{m}_{2}$ (lama pengasapan $48 \mathrm{jam}$ ), $\mathrm{m}_{3}$ (lama pengasapan $48 \mathrm{jam}$ ), $\mathrm{m}_{4}$ (lama pengasapan 48 jam), dan $\mathrm{m}_{5}$ (lama pengasapan 48 jam). Telur asin tersebut sebelum dilakukan pengasapan, dikukus terlebih dahulu dalam panci kemudian bersihkan abu dari telur menggunakan air dan keringkan.

Setelah itu, lakukan pengasapan pada tungku pengasap berbahan aluminium 
berukuran 165 x 75 x $60 \mathrm{~cm}$ di ruangan terbuka untuk memperlancar proses perapian. Tungku terdiri atas dua kompartemen, yaitu bagian atas (untuk meletakkan telur) tersusun 4 buah rak vertikal dan bagian bawah (untuk tempat sabut kelapa), serta terdapat sebuah pipa untuk menyalurkan panas dari kompartemen bawah ke atas. Sabut kelapa sebanyak $1,5 \quad \mathrm{~kg}$ dibakar untuk menghasilkan bara api kemudian tutup kompartemen. Agar bara api menyala secara maksimal maka ventilasi udara perlu diatur dengan membuka 1/3 katup inlet pada kabinet pengasap dan $1 / 4$ katup outlet. Proses pengasapan menggunakan suhu $60^{\circ} \mathrm{C}$ (Darmadji dan Triyudiana, 2006). Letakkan telur asin pada rak-rak selam \pm 8 jam dan lakukan pemindahan rak setiap 2-3 jam hingga dicapai lama pengasapan sesuai perlakuan. Pengelapan telur dapat dilakukan setelah $\pm 42-52$ jam telur dikeluarkan dari tungku agar jelaga bisa dibersihkan. Pisahkan sampel sesuai perlakuan.

\section{Penyajian Sampel}

1) Sampel yang digunakan sebanyak 20 sampel/panelis.

2) Setiap panelis akan mendapatkan 5 sampel telur asin asap dengan kode yang berbeda.

3) Letakkan sampel di piring.

\section{Pemberian Kode Sampel}

1) Penamaan sampel harus dilakukan sedemikian rupa sehingga penelis tidak dapat menebak isi sampel tersebut berdasarkan penamaannya.

2) Kode diberikan secara random.

3) Jangan sampai terjadi duplikasi (tidak boleh 2 sampel kodenya sama).

\section{Pengamatan dan Pengujian}

Pengamatan dan pengujian sampel yang dilakukan adalah sebagai berikut:

1) Susut bobot telur (\%)

Susut bobot telur perlu diamati untuk mengetahui seberapa besar terjadinya penguapan air dan hilangnya karbondioksida dari putih telur melalui kulit telur selama penyimpanan. Susut bobot telur dapat diukur dengan timbangan elektrik (Romanoff dan Romanoff, 1963).

Rumus Susut Bobot Telur (\%)

$$
=\frac{\mathrm{B}_{1}-\mathrm{B}_{2}}{\mathrm{~B}_{1}} \times 100 \%
$$

Keterangan: $\mathrm{B}_{1}=$ Bobot telur sebelum

$$
\text { pengasapan }
$$

$\mathrm{B}_{2}=$ Bobot telur setelah pengasapan

2) Uji organoleptik

a. Sampel yang sudah diberikan kode diletakan diatas meja.

b. Panelis diberikan form pengisian uji organoleptik.

c. Panelis dijelaskan tentang prosedur pengisian form dan dipersilahkan mengisi form uji organoleptik satu persatu.

d. Panelis yang belum mendapat giliran mengisi form berada di ruangan tunggu.

e. Form dikumpulkan kembali untuk dilakukan analisis data selanjutnya.

Uji organoleptik dilakukan menggunakan metode uji mutu hedonik oleh 20 panelis agak terlatih (Kartika et. al., 2012).

a. Kemasiran

\begin{tabular}{|c|c|c|c|c|c|}
\hline 1 & 2 & 3 & 4 & 5 & 6 \\
\hline
\end{tabular}

b. Tekstur

\begin{tabular}{|c|c|c|c|c|c|}
\hline 1 & 2 & 3 & 4 & 5 & 6 \\
\hline
\end{tabular}

c. Aroma khas asap

\begin{tabular}{|c|c|c|c|c|c|}
\hline 1 & 2 & 3 & 4 & 5 & 6 \\
\hline
\end{tabular}

d. Tingkat kesukaan

\begin{tabular}{|c|c|c|c|c|c|}
\hline 1 & 2 & 3 & 4 & 5 & 6 \\
\hline
\end{tabular}

Setiap panelis mendapatkan 5 sampel dan 1 air mineral (Gambar 1.) sebelum melakukan uji organoleptik terhadap telur asin asap. Diharapkan 20 panelis tersebut dapat melaporkan hasil uji organoleptik dengan sejujur-jujurnya. Setiap panelis mendapatkan 5 sampel dan 1 air mineral (Gambar 1.) sebelum melakukan uji organoleptik terhadap telur asin asap. Diharapkan 20 panelis tersebut dapat melaporkan hasil uji organoleptik dengan 
sejujur-jujurnya.

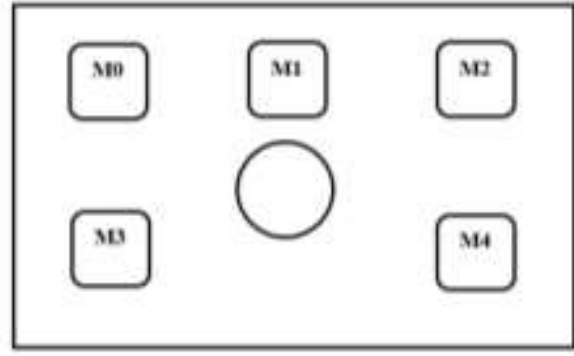

Gambar 1. Contoh denah penempatan sampel telur asin asap dan air mineral untuk uji organoleptik oleh responden

Keterangan :

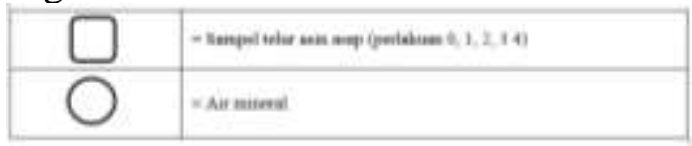

\section{Pengujian}

\section{1) Ruang Pengujian}

Ruang pengujian yang digunakan yaitu ruangan yang terisolasi sehingga dapat dihindarkan komunikasi antarpanelis, suhu ruang yang cuku sejuk $\left(20-25^{\circ} \mathrm{C}\right)$ dengan mempunyai sumber cahaya yang baik dan netral, karena cahaya dapat mempengaruhi warna sampel yang diuji.

Tempat tunggu panelis harus cukup nyaman agar anggota panel cukup sabar menanti gilirannya. Tidak disarankan adanya komunikasi antarpanelis yang sudah melakukan uji organoleptik dengan panelis yang belum melakukan uji sehingga harus ada disediakan tempat yang terpisah hal ini bertujuan agar tidak mempengaruhi pemberian penilaian terhadap sampel uji.

\section{2) Rincian Variabel Uji Organoleptik Sampel}

a. Kemasiran adalah sifat organoleptik/inderawi yang hanya dapat dikenali dengan pengamatan menggunakan indera pengecap, peraba dan penglihatan. Kemasiran menyatakan tekstur makanan yang dirasakan oleh mulut terutama yang berhubungan dengan kesan berbutir-butir seperti pasir (Suhardjo, 1992).

b. Tektsur merupakan uji organoleptik penginderaan yang dihubungkan dengan rabaan atau sentuhan dan tekstur merupakan suatu sifat karakteristik kelenturan dari produk yang berbentuk padat. c. Aroma merupakan salah satu parameter penilaian organoleptik terhadap suatu produk. Pada umumnya bau yang diterima oleh hidung dan otak lebih banyak merupakan berbagai ramuan atau campuran empat bahan utama yaitu harum, asam, tengik dan hangus (Winarno, 2004).

d. Tingkat kesukaan merupakan suatu cara dimana panelis diminta memberi tanggapan pribadi mengenai preferensi tentang kesukaan atau ketidaksukaan pada sampel uji.

\section{Analisis Data}

Data kualitas eksterior yang diperoleh dilakukan uji homogenitas data. Apabila hasil uji tersebut normal akan dilanjutkan dengan analisis sidik ragam (ANOVA). Jika analisis ragam terdapat perbedaan nyata atau sangat nyata maka dilanjutkan dengan uji nilai tengah menggunakan Uji Lanjut Berganda Duncan (DMRT). Sedangkan analisis data hasil uji organoleptik yang diperoleh dilakukan dengan menggunakan uji Kruskal Wallis (Kartika, et. al., 1988; Soekarto, 1998). Jika pengujian terdapat pengaruh maka akan dilanjutkan dengan Uji Perbandingan Ganda Dunn (Dunn Test).

HASIL DAN PEMBAHASAN

\section{Susut Bobot Telur}

Hasil analisis statistik terhadap rataan susut 
bobot telur asin asap disajikan pada Tabel

1.

Tabel 1. Rataan susut bobot telur asin asap

\begin{tabular}{lc}
\hline \multicolumn{1}{c}{ Media Pengasapan } & Susut bobot telur $(\%)$ \\
\hline $\mathrm{m}_{0}:$ Tanpa Media Pengasapan & $1,470^{\mathrm{a}}$ \\
$\mathrm{m}_{1}:$ Sabut Kelapa & $7,205^{\mathrm{b}}$ \\
$\mathrm{m}_{2}$ : Serbuk Gergaji & $10,053^{\mathrm{c}}$ \\
$\mathrm{m}_{3}:$ Sekam & $16,545^{\mathrm{d}}$ \\
$\mathrm{m}_{4}:$ Kulit Kayu Galam & $21,700^{\mathrm{e}}$ \\
\hline
\end{tabular}

Keterangan: Angka dengan superskrip yang berbeda dalam kolom yang sama menunjukkan perbedaan yang sangat nyata $(\mathrm{P}<0,01)$

Berdasarkan hasil analisis statistik pada uji eksterior menunjukkan bahwa media pengasapan yang berbeda berpengaruh sangat nyata terhadap susut bobot (\%) telur asin asap. Tingkat penurunan/susut bobot (\%) telur asin asap dengan menggunakan media pengasapan yang berbeda secara berurutan adalah 1,470 $\left(\mathrm{m}_{0}\right) ; 7,205\left(\mathrm{~m}_{1}\right) ; 10,053\left(\mathrm{~m}_{2}\right) ; 16,545\left(\mathrm{~m}_{3}\right)$ dan 21,700 $\left(\mathrm{m}_{4}\right)$. Terjadinya penyusutan bobot akibat adanya aktivitas garam dalam menarik air yang erat kaitannya dengan peristiwa plasmolysis. Air akan bergerak dari konsentrasi garam rendah ke konsentrasi garam tinggi karena adanya perbedaan tekanan osmosis. Garam dengan konsentrasi rendah berfungsi sebagai pembentuk cita rasa, sedangkan dalam konsentrasi tinggi mampu berperan sebagai pengawet.

Kandungan yang berperan dalam pengawetan telur asin adalah kandungan klorida yang dapat ditemui pada garam dan bahan lainnya seperti kayu galam, sabut kelapa, sekam, dan serbuk gergaji. Fungsi klorida sebagai pengawet karena sifat osmotiknya yang tinggi, kemampuan mengikat air, dan mengakibatkan denaturasi protein. Garam (klorida) dalam larutan akan terionisasi menjadi ion $\mathrm{Cl}$ ini bersifat toksik bagi mikroba (Soeparno, 1994 dalam Asih et. al., 2011). Pernyataan serupa juga dikemukakan oleh Hari (2004) dalam Asih, et. al., (2011) menyatakan berkurangnya air pada telur asin menyebabkan telur menjadi lebih awet, garam (klorida) akan masuk ke dalam telur dengan cara merembes ke pori-pori kulit, menuju bagian putih, dan akhirnya ke kuning telur (Salim, et. al., 2017).

Semakin banyak asap yang masuk, maka semakin tinggi pula penyusutan bobot telur. $\mathrm{m}_{4}$ (kulit kayu galam) memiliki penyusutan bobot telur paling tinggi jika dibandingkan media pengasapan lainnya. Hal ini dikarenakan kandungan fenol yang dimiliki $\mathrm{m}_{4}$ diduga paling tinggi, sehingga asap yang dihasilkan lebih hitam pekat. Menurut penelitian Yulita, et. al., (2011) terbentuknya warna hitam disebabkan karena adanya senyawa-senyawa golongan karbonil dan senyawa fenol. Kadar fenol dari asap cair serbuk kayu gelam yaitu $0,3514 \mathrm{mg} / \mathrm{L}$. Semakin cepat asap hitam pekat yang dihasilkan menandakan bahwa semakin cepat pula penyusutan bobot telur (pengamatan secara visual tanpa analisis statistik). Sehingga lama pengasapan 48 jam pada semua media pengasapan menghasilkan penyusutan yang berbeda pula. Selain itu, aroma khas asap telur yang dihasilkan $\mathrm{m}_{4}$ paling kuat dibandingkan media pengasapan lainnya selaras dengan penyusutan bobotnya.

Kandungan selulosa dan lignin yang terdapat pada media pengasapan juga mempengaruhi asap yang dihasilkan. Kandungan selulosa dan lignin yang dimiliki $\mathrm{m}_{1}$ (sabut kelapa) adalah $23 \%-43 \%$ selulosa dan $35 \%$ - 45\% lignin sementara $\mathrm{m}_{3}$ (sekam padi) sekitar $50 \%$ selulosa dan 25-30\% lignin (Haryadi, 2006). Didapat penyusutan bobot telur asin asap $\mathrm{m}_{1}$ $(7,205 \%)$ lebih rendah dibandingkan dengan $m_{3}(16,545)$. Hal ini menunjukkan bahwa semakin tinggi kadar selulosa maka penyusutan bobot telur asin asap juga semakin tinggi. Akan tetapi, semakin tinggi 
kadar lignin menyebabkan penyusutan bobot telur asin asap lebih rendah. Sesuai pernyataan Wijaya et. al., (2008) bahwa asap cair dari hasil pembakaran mengandung berbagai senyawa yang terbentuk karena terjadinya pirolisis tiga komponen kayu yaitu selulosa, hemiselulosa dan lignin.

\section{Sifat Organoleptik}

\section{Kemasiran}

Hasil analisis statistik uji Kruskal Wallis terhadap rataan uji organoleptik kemasiran telur asin asap disajikan pada Tabel 2.

Tabel 2. Rataan uji organoleptik kemasiran telur asin asap

\begin{tabular}{lrrrr}
\hline \multicolumn{1}{c}{ Media Pengasapan } & Kemasiran & Tekstur & $\begin{array}{r}\text { Aroma khas } \\
\text { asap }\end{array}$ & $\begin{array}{c}\text { Tingkat } \\
\text { kesukaan }\end{array}$ \\
\hline $\mathrm{m}_{0}$ : Tanpa Media Pengasapan & $3,70^{\mathrm{b}}$ & 3,45 & $4,75^{\mathrm{c}}$ & 3,15 \\
$\mathrm{~m}_{1}$ : Sabut Kelapa & $2,70^{\mathrm{a}}$ & 3,75 & $2,55^{\mathrm{a}}$ & 2,95 \\
$\mathrm{~m}_{2}$ : Serbuk Gergaji & $3,90^{\mathrm{b}}$ & 2,90 & $3,45^{\mathrm{b}}$ & 2,80 \\
$\mathrm{~m}_{3}$ : Sekam & $3,85^{\mathrm{b}}$ & 3,45 & $2,80^{\mathrm{ab}}$ & 2,85 \\
$\mathrm{~m}_{4}$ : Kulit Kayu Galam & $3,15^{\mathrm{ab}}$ & 3,10 & $2,50^{\mathrm{a}}$ & 3,15 \\
\hline
\end{tabular}

Keterangan: Angka dengan superskrip yang berbeda dalam kolom yang sama menunjukkan perbedaan yang nyata $(\mathrm{P}<0,05)$.

Berdasarkan hasil pengujian panelis, diperoleh hasil bahwa media yang berbeda mempengaruhi tingkat kemasiran telur asin asap. Skor tingkat kemasiran pada penelitian ini berturut-turut adalah 2,70 ( $\left.\mathrm{m}_{1}\right) ; 3,15$ $\left(\mathrm{m}_{4}\right) ; 3,70\left(\mathrm{~m}_{0}\right) ; 3,85\left(\mathrm{~m}_{3}\right)$ dan 3,90 $\left(\mathrm{m}_{2}\right)$ pada Tabel 2. Perlakuan $m_{1}$ (media pengasapan menggunakan sabut kelapa) memiliki skor tingkat kemasiran tertinggi yaitu 2,70 (paling masir dibanding perlakuan lainnya). Adapun perlakuan $\mathrm{m}_{2}$ (media pengasapan menggunakan serbuk gergaji) memiliki skor kemasiran terendah yaitu 3,90 (tidak begitu masir) dan tidak berbeda nyata dengan perlakuan $m_{0}$ (tanpa pengasapan) dan $m_{3}$ (media pengasapan menggunakan sekam).

Kandungan senyawa fenol yang terdapat pada sabut kelapa juga sangat tinggi yaitu 25,99\% lebih tinggi dari kandungan fenol pada tempurung kelapa yaitu 19,9\% (Yefrida, et. al., 2008). Tingginya kandungan fenol mempengaruhi perbedaan tekstur dari telur asin asap yang telah disimpan akibat adanya kandungan lemak pada telur asin asap. Hal ini sejalan dengan pendapat Djaafar (2007) bahwa lemak dalam telur berfungsi meningkatkan citarasa, memperbaiki tekstur dan sebagai pembawa flavor. Selain itu, menurut penelitian dari Djaafar (2007) senyawa fenol sebagai antioksidan mampu menghambat oksidasi lemak dengan menstabilkan radikal bebas.
Oleh sebab itu, sabut kelapa dapat dijadikan sebagai bahan bakar terbaik untuk meningkatkan kemasiran pada telur asin asap.

Menurut pernyataan Muchtadi dan Sugiyono (1992), bahwa pemanasan dan penambahan $\mathrm{NaCl}$ dapat memecah emulsi telur dengan merusak keseimbangan fase polar (protein) dan fase non polar sehingga garam dapat masuk ke dalam kuning telur (telur menjadi masir). Skor kemasiran turut dipengaruhi susunan serat dari media pengasapan. $\mathrm{m}_{1}$ (sabut kelapa) memiliki skor kemasiran tertinggi yaitu 2,70 (paling masir) ternyata mengandung $75 \%$ serat (Carrijo, et. al., 2002). Jika dibandingkan dengan $\mathrm{m}_{3}$ (sekam) memiliki kandungan serat silika sebesar $15-20 \%$, yang menghasilkan skor kemasiran 3,80 (kurang masir). Diduga kandungan serat mampu meningkatkan kemasiran pada telur asin asap. Sedangkan skor kemasiran $\mathrm{m}_{1}$ (sabut kelapa) dengan $\mathrm{m}_{4}$ (kulit kayu galam) tidak berbeda nyata. Hal ini dikarenakan kayu galam memiliki serat pada kulit galam berlapis-lapis sehingga skor kemasiran $\mathrm{m}_{4}$ yaitu sebesar 3,15 (masir) tidak jauh berbeda dengan $\mathrm{m}_{1}$. Selain itu, penentuan skor kemasiran menggunakan media yang berbeda tergantung dari preferensi yang sesuai dengan selera panelis. 


\section{Tekstur}

Berdasarkan hasil analisis statistik pada Tabel 2 menunjukkan bahwa media yang berbeda tidak berpengaruh terhadap skor tekstur pada uji organoleptik telur asin asap. Skor organoleptik tekstur pada penelitian ini berturut-turut adalah 2,90 $\left(\mathrm{m}_{2}\right) ; 3,10\left(\mathrm{~m}_{4}\right) ; 3,45\left(\mathrm{~m}_{0}\right) ; 3,45\left(\mathrm{~m}_{3}\right)$ dan 3,75 $\left(\mathrm{m}_{1}\right)$. Meskipun secara statistik tidak ditemukan adanya perbedaan nyata pada tekstur, skor tekstur organoleptik berkisar antara 2,90 (kenyal) hingga 3,75 (agak kenyal). Terjadinya perbedaan tekstur dari telur asin asap yang telah disimpan disebabkan oleh kandungan lemak dari telur asin asap. Sesuai dengan pendapat Djaafar (2007) bahwa lemak dalam telur berfungsi meningkatkan citarasa, memperbaiki tekstur dan sebagai pembawa flavor. Peningkatan kekenyalan ini disebabkan pada pengasapan terjadi proses pemanasan dimana komponen air yang ada pada telur mengalami proses penguapan.

\section{Aroma Khas}

Berdasarkan hasil uji panelis tentang aroma khas asap pada telur asin asap dipengaruhi oleh media pengasapan yang berbeda. Skor aroma khas asap pada penelitian ini berturut-turut adalah 2,50 $\left(\mathrm{m}_{4}\right)$; 2,55 $\left(\mathrm{m}_{1}\right) ; 2,80\left(\mathrm{~m}_{3}\right) ; 3,45\left(\mathrm{~m}_{2}\right)$ dan 4,75 $\left(\mathrm{m}_{0}\right)$ pada Tabel 4. Perlakuan $\mathrm{m}_{4}$ (media pengasapan menggunakan kulit kayu galam), $\mathrm{m}_{1}$ (media pengasapan menggunakan sabut kelapa), dan $\mathrm{m}_{3}$ (media pengasapan menggunakan sekam) tidak menunjukkan perbedaan nyata pada skor aroma khas asap yaitu 2,50; 2,55 dan 2,80 (aroma asap kuat). Akan tetapi skor aroma khas asap berbeda nyata terhadap $\mathrm{m}_{2}$ (media pengasapan menggunakan serbuk gergaji) dan $m_{0}$ (tanpa pengasapan) yaitu 3,45 (aroma asap lemah) dan 4,75 (aroma asap tidak terasa). Hal ini sesuai dengan pernyataan Tanu et. al., (2014) bahwa pengasapan dapat menggunakan kayu yang bertekstur keras dan menghasilkan asap yang banyak dan tahan lama apabila dibakar seperti tempurung kelapa.

Bau khas pada telur asin asap berasal dari fenol yaitu senyawa utama pembentuk aroma asap (Soeparno, 2005). Senyawa ini masuk kedalam bagian dalam telur melalui pori-pori kerabang telur dan menempel pada bagian dalam telur baik putih dan kuning telur. Diduga bahan kandungan fenol pada kulit kayu galam $\left(\mathrm{m}_{4}\right)$ cukup tinggi dibandingkan media lainnya yaitu sebesar 2,50 (aroma khas asap kuat). Menurut penelitian Wardhani, et. al., (2018), konsentrasi total fenol yang terdapat pada ekstrak kulit kayu galam sebesar 33,8646 ppm dengan kadar total fenol sebesar 30,47814 mg GAE/g ekstrak. Media pengasapan sabut kelapa $\left(\mathrm{m}_{1}\right)$ memiliki skor aroma khas asap yang tidak berbeda nyata dengan $\mathrm{m}_{4}$ yaitu 2,55 (aroma khas asap kuat). Hal ini diduga kandungan fenol sabut kelapa yang tidak jauh berbeda dengan kulit galam. Bahkan fenol yang terdapat pada sabut kelapa lebih tinggi daripada kandungan fenol yang terdapat pada tempurung kelapa (Arif, et. al., 2015).

\section{Tingkat Kesukaan}

Berdasarkan hasil analisis statistik pada Tabel 2. menunjukkan bahwa media yang berbeda tidak berpengaruh terhadap skor tingkat kesukaan pada telur asin asap. Skor tingkat kesukaan pada penelitian ini berturut-turut adalah 2,80 $\left(\mathrm{m}_{2}\right) ; 2,85\left(\mathrm{~m}_{3}\right)$; $2,95 \quad\left(\mathrm{~m}_{1}\right) ; 3,15 \quad\left(\mathrm{~m}_{4}\right)$ dan 3,15 $\left(\mathrm{m}_{0}\right)$. Meskipun secara statistik tidak ditemukan adanya perbedaan nyata pada tingkat kesukaan, skor tingkat kesukaan berkisar antara 2,80 (lebih suka) hingga 3,75 (suka). Perbedaan tingkat kesukaan oleh panelis bergantung dari preferensi selera dari panelis itu sendiri, sehingga belum bisa ditentukan berdasarkan jenis media pengasapan apa yang menghasilkan perbedaan yang sangat nyata. Hal ini dikarenakan umumnya tingkat kesukaan panelis semakin meningkat dengan semakin lama produk telur asin diperamkan/diasapkan.

\section{KESIMPULAN}

Media pengasapan berpengaruh terhadap kemasiran, aroma khas asap, dan penyusutan bobot telur asin asap. Untuk aroma asap media kulit galam yang 
memberikan aroma asap yang paling kuat, namun kelemahannya adalah memiliki bopenyusutan bobot telur yang paling tinggi. Media pengasapan sabut kelapa dan kulit galam menghasilkan kemasiran yang paling tinggi diantara media lain.

\section{DAFTAR PUSTAKA}

Al-Baarri, A., Setiani, B., Siregar, R., \& Sumekar, W. (2016). Hardness dan Optical Properties dari Itik Asap dengan Variasi Penggunaan Suhu Oven. Jurnal Aplikasi Teknologi Pangan, 5(4), 146-148. doi: http://dx.doi.org/10.17728/jatp.219.

Amir, S., Saifuddin S., \& Jafar, N. (2014). Pengaruh Konsentrasi Garam dan Lama Penyimpanan terhadap

Kandungan Protein dan Kadar Garam Telur Asin. Skripsi. Makassar: Program Studi Ilmu Gizi Fakultas Kesehatan Masyarakat Universitas Hasanuddin.

Arif, A.R., Asri Saleh, \& Jawiana Saokani. (2015). Adsorpsi Karbon Aktif dari TempurungKluwak (Pangium edule) terhadap Penurunan Fenol. Jurnal Al Kimia, 3(1), 34-47 DOI: https://doi.org/10.24252/alkimia.v3i1.1659.

Asih, Wijayanti, \& Sugiarto. (2011). Pengaruh konsentrasi keragenan dan gula pasir terhadap sifat fisikokimia dan organoleptik jelly drink alang-alang (Imperata

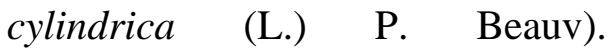
Undergraduate Thesis. Surabaya: Widya Mandala Catholic University.

Ayustaningwarno, F. (2014). Teknologi Pangan Teori Praktis dan Aplikasi. Yogyakarta: Graha Ilmu.

Baharuddin, Arfah, M. T., \& Syahidah. (2005). Pemanfaatan Serbuk Kayu Jati (Tectona grandis L.) yang Direndam Dalam Air Dingin
Sebagai Media Tumbuh Jamur Tiram (Pleurotus comunicipae). Jurnal Perennial, 2(1) : 1-5. DOI: http://dx.doi.org/10.24259/perennia l.v2i1.146.

Chandra, M. A. (2014). Kualitas telur ayam ras yang diperdagangkan di pasar tradisionalkota Pekanbaru. Skripsi. Pekanbaru: Jurusan Ilmu Peternakan Fakultas Pertanian dan Peternakan UIN Sultan Syarif Kasim Riau.

Carrijo, O.A., Liz, R.S., Makishima, N., (2002). Fiber of green coconut shell as an agricultural substrate. Hortic. Bras. [online], 20(4), 533-535. http://dx.doi.org/10.1590/S010205362002000400003.

Darmadji, P., \& Triyudiana, H. (2014). Proses Pemurnian Asap Cair dan Simulasi Akumulasi Kadar

Benzopyrene pada Proses Perendaman Ikan.agriTECH, 26(2). doi: http://dx.doi.org/10. 22146/agritech. 9477.

Djaafar, TF. (2007). Telur Asin Omega-3 Tinggi. Warta Penelitian dan Pengembangan Pertanian. 29(4): 4-5. Retrieved from http://203.190.37.42/publikasi/wr2940 78.pdf.

Haryadi. (2006). Teknologi Pengolahan Beras. Yogyakarta: Gajah Mada Universitas Press.

Hasrah. (2017). Karakteristik Organoleptik Telur Asin yang Diberikan Kombinasi Bawang Putih (Allium sativum) dan Cabai (Capsicum annum L.) pada Lama Penyimpanan yang Berbeda. Skripsi. Makassar: Fakultas Peternakan Universitas Hasanuddin.

Jaelani, A., \& M.I. Zakir. (2018). Kualitas Organoleptik Telur Asin Asap dengan Lama Pengasapan erbeda. 
Prosiding Hasil-Hasil Penelitian Dosen-Dosen Uniska MAB Mei 2018. Banjarmasin: Uniska MAB.

Kartika, B., P. Hastuti \& W. Supartono. (1988). Uji Indrawi Bahan Pangan. Yogyakarta: Pusat Antar Universitas Pangan dan Gizi UGM.

Marsudin, S. (2009). Pengaruh Beberapa Bahan Pengawet Nabati terhadap Nilai Haugh Unit, Berat dan Kualitas Telur Konsumsi Selama P enyimpanan. Lampung: Balai Pengkajian Teknologi Pertanian Lampung.

Muchtadi T.R., dan Sugiono. (1992). Ilmu Pengetahuan Bahan Pangan. Bogor: PAU Pangan dan Gizi IPB.

Munir I. M. \& Wati, R. S. (2014). Uji organoleptik telur asin dengan konsentrasi garam dan masa peram yang berbeda. Prosiding Seminar Nasional Teknologi Peternakan dan Veteriner. DOI: http://dx.doi.org/10.14334/Pros. Semnas.TPV-2014-p.646-649.

Novia, D., I. Juliyarsi, \& G. Fuadi. (2012). Kadar Protein, Kadar Lemak dan Organoleptik Telur Asin Asap Berbahan Bakar Sabut Kelapa. Jurnal Peternakan. Vol. 9(1), 35-45 DOI: http://dx.doi.org/10.24014/ jupet.v9i1.169.

Oktaviani, H., N. Kaniadadan N. R. Utami. (2012). Pengaruh Pengasinan terhadap Kandungan Zat Gizi Telur Bebek yang Diberi Limbah Udang. Jurnal Unnes of Life Science, 1(2),106-112. https://journal .unnes.ac.id/sju/index.php/Unnes JLifeSci/article/ view/910.

Rifaid. (2018). Kualitas dan Produksi Telur Berdasarkan Umur dan Pakan Yang Digunakan. Skripsi. Makasar: Jurusan Ilmu Peternakan Fakultas
Sains dan Teknologi Universitas Islam Negeri Alauddin.

Romanoff, A.L. \& A.J. Romanoff. (1963). The Avian Egg. New York: John Willey and Sons Inc.

Salim, E., Syam, H. \& Wijaya, M. (2017). Pengaruh Variasi Waktu Pemeraman Telur Asin dengan Penambahan Abu Sabut Kelapa terhadap Kandungan Kadar Klorida, Kadar Protein dan Tingkat Kesukaan Konsumen. Jurnal Pendidikan Teknologi Pertanian, 3 (2), 107-116. DOI: https://doi.org/10.26858/jptp.v3i2.5 522.

Simanjuntak, O. Estrada, S. Wasito, K. Widayaka. (2013). Pengaruh Lama Pengasapan Telur Asin dengan Menggunakan Serabut Kelapa terhadap Kadar Air dan Jumlah Bakteri Telur Asin Asap. Jurnal Ilmiah Peternakan, 1(1), 195 -200. Retrived from http://id.portalgarudaorg/?ref=browse \&mod=viewarti cle $\&$ article $=95642$.

Soekarto, S.T. (1998). Penelitian Organoleptik Untuk Industri Pangan dan Hasil Pertanian. Yogyakarta: Liberty.

Soeparno. (2005). Ilmu dan Teknologi Daging. Yogyakarta: Gadjah Mada University Press.

Sugiyono. (2018). Metode Penelitian Administrasi. Bandung: Alfabeta.

Suhardjo. (1992). Kajian Fenomena Kemasiran Buah Apel (Malus sylvestris Mill) Kultivar 'Rome Beauty'. Tesis. Bogor: Institut Pertanian Bogor.

Sutiasih, T., Yuliandri, L. A., \& Falahudin, A. (2017). Pengaruh Perendaman Ekstrak Teh Hijau (Camellia sinensis) terhadap Nilai Susut Bobot 
dan Sifat Organoleptik Telur Ayam Ras. Jurnal Ilmu Pertanian dan Peternakan 5(2), 204-210. Retrieved from http://jurnal. unma.ac.id/index.php/AG/article/vi ew/752.

Tanu, S., Rihi, J., \& Manu, A. (2019). Pengaruh Pengasapan Menggunakan Tempurung Kelapa (Cocos nucifera L.) terhadap Aspek Organoleptik dan Mikrobiologi Telur Itik Asin. Jurnal Nukleus Peternakan, 1(2), 149-157. Retrieved from https://ejurnal. undanaac.id/nukleus/article/view/7 59.

Wardhani, R. R. A. A. K., Akhyar, O. \& Prasiska, E. (2018). Analisis Skrining Fitokimia, Kadar Total Fenol- Flavonoid dan Aktivitas Antioksi dan Ekstrak Etanol Kulit Kayu Tanaman Galam Rawa Gambut (Melaleuca cajuputi Roxb). Jurnal AI Ulum Sains dan Teknologi, 4(1), 39-45.DOI: http://dx.doi.org/10. 31602/ajst.v4i1.1589.

Wasito dan Rohaeni, E. S. (1994). Beternak Itik Alabio. Yogyakarta: Kanisius.

Wijaya, M., Noor, E., Irawadi, T. T., \& Pari,
G. (2008). Karakterisasi Komponen Kimia Asap Cair dan Pemanfaatan nya Sebagai Biopestisida. Jurnal Bionature, 9(1), 34-40.

Widjaja, K. (2003). Peluang Bisnis Itik. Jakarta: Penebar Swadaya.

Widyastuti, S., Saloko, S., \& Murad, R. (2012). Optimasi Proses Pembuatan Asap Cair Dari Tempurung Kelapa Sebagai Pengawet Makanan dan Prospek Ekonomisnya. Jurnal Agroteksos, 22, 48-58.

Winarno, F.G. (2004). Kimia Pangan dan Gizi. Jakarta: Gramedia Pustaka Utama.

Yefrida, Putri, Y. K., Silvianti, R., Lucia, N., Refilda, \& Indrawati. (2008). Pembuatan Asap Cair Dari Limbah Kayu Suren (Toona sureni), Sabut Kelapa dan Tempurung Kelapa (Cocos nucifera Linn). Jurnal Ris Kim, 1(2). DOI:https://doi.org/10. 25077/jrk,vl i2.85.

Yulita, E., Hamzah, B., \& Wijaya, A. (2011). Pemanfaatan Asap Cair Serbuk Kayu Sebagai Koagulan Bokar. Jurnal Dinamika Penelitian Industri 22(1), 58-62. http://dx.doi. org/10.28959/ jdpi. v22i1.540. 